\title{
Online Assessment Methods and Instrument Testing Aided by Google Meet and WhatsApp Applications
}

\author{
Johan Syahbrudin ${ }^{1,2, ~ *}$, Anita Anggraini ${ }^{3}$, Purwoko Haryadi Santoso ${ }^{1}$, Syamsul \\ Bahri $^{1}$
}

1 Educational Research and Evaluation Study Program, Universitas Negeri Yogyakarta, Indonesia

2 Department of Informatics Engineering, Faculty of Engineering, Universitas Pamulang, Indonesia

3 Technology and Vocational Education Study Program, Universitas Negeri Yogyakarta, Indonesia

* Corresponding author. Email: johansyahbrudin.2021@student.uny.ac.id

\begin{abstract}
Many educators still have difficulty in conducting online assessments, especially for those who have not been facilitated by the Learning Management System application or the like. Therefore, this study aims to develop an online assessment method that is effective and can be easily carried out by almost every educator even if they are new to using social media applications such as WhatsApp. This research is a Research and Development (R\&D) which is adapted from the 4-D model with 4 stages, namely (1) define, includes observation and journal analysis to determine the specifications of the assessment method that will be developed as needed by educators and students in online teaching/learning; (2) designs; (3) develop, which includes the development and testing of products imposed on a physics lecturer and engineering student at a private university in Banten; and (4) disseminate, through scientific publication of this research results. Apart from observation, data were also collected using interview and document analysis methods which were then analyzed qualitatively. The findings of this study indicate that the online assessment method that can be used by almost all educators during this pandemic is familiar social media applications such as WhatsApp. An online assessment method that is effective and easy to apply is by giving test questions directly through Google Meet or zoom meetings with a certain time duration for each question, and sending the answers via WhatsApp. This effectiveness and convenience is based on the results of interviews with research subjects who have used this method with the help of the Google Meet and WhatsApp applications where they find it easy to organize and evaluate learning outcomes. The results of the assessment also show the actual abilities of students because it is very difficult to be able to cheat or cooperate. In addition, the results of this assessment are also very useful for testing the quality of the questions themselves. So this method helps educators to measure the achievement of the competence of their students as well as to validate the test instruments that have been developed.
\end{abstract}

Keywords: instrument testing, google meet, online assessment method, whatsapp

\section{INTRODUCTION}

The coronavirus pandemic or Corona Virus Disease19 (Covid-19) has had many impacts on various aspects of Indonesian people's lives, including in the realm of education. This has forced the government to issue social distancing and physical distancing policies to prevent more massive and widespread transmission of the virus. Learning activities can be done online, where this policy is deemed appropriate, at least in terms of health. However, for the effectiveness of learning, it still needs to be prepared carefully.

Online learning, whether it is asynchronously through the Learning Management System (LMS), emodules and video tutorials, or synchronously via video conference with various delivery methods such as lectures, presentations, or demonstrations, has 
implications for how the assessment process or assessment of learning outcomes can be done while maintaining the validity, effectiveness, and practicality. Assessment is a very important part of learning [1]. This is very important to do because assessment is all methods to collect information about students' knowledge, abilities, understanding, attitudes, and motivations, which can be done through tests and selfassessments, both formally and informally [2] for decision making both related to the curriculum or the learning process as an effort to increase the effectiveness of learning [3].

For educators who are familiar with and facilitated with various online learning tools through LMS, perhaps the assessment of learning outcomes, especially the cognitive aspect, is not a serious obstacle, but for educators who are just used to social media applications and do not have LMS facilities or the like, it certainly creates its own problems. As is the case in elementary and secondary schools in Lampung, especially schools in remote villages, where the assessment process for learning outcomes is only limited to take-home exams where students are asked to come to school to take exam questions in accordance with the protocol. health and a predetermined schedule, then students collect the answers the next day while taking questions for the next subject. Of course this raises its own problems where the results of the assessment do not show the actual results or abilities of the students because it is very difficult to control that the questions are done by the students themselves. And even if it is done by the students themselves, the results do not necessarily show the abilities they have mastered because students can open books or access the internet, especially if the questions given are in the form of multiple choice questions. For educators who are familiar and facilitated with various online learning tools through LMS maybe the assessment of learning outcomes, especially the cognitive aspect, is not a serious obstacle, but for educators who are just used to social media applications and do not have LMS facilities or the like, it certainly creates its own problems. As is the case in elementary and secondary schools in Lampung, especially schools in remote villages, where the assessment process for learning outcomes is only limited to take home exams where students are asked to come to school to take exam questions in accordance with the protocol. health and a predetermined schedule, then students collect the answers the next day while taking questions for the next subject. Of course this raises its own problems where the results of the assessment do not show the actual results or abilities of the students because it is very difficult to control that the questions are done by the students themselves. And even if it is done by the students themselves, the results do not necessarily show the abilities they have mastered because students can open books or access the internet, especially if the questions given are in the form of multiple choice questions.

This shows that the assessment process that has been carried out still has many shortcomings, and that is only seen from the process, not to mention the quality of the instrument. In fact, it is the duty of an educator to be able to assess the learning outcomes of their students by using appropriate instruments and tested for their validity and reliability. Furthermore, the results of the assessment are useful for decision making as an effort to improve learning effectiveness.

Actually, there are several alternative assessments during distance learning during the Covid-19 pandemic, including online-based assessments, portfolio assessments, and self-assessments [4]. And specifically for online-based assessment, there is one way or method that can be applied even though it does not have online learning facilities such as LMS and the like, namely by using an online assessment method that is effective and easy to do by almost all educators by utilizing familiar social media applications. again like WhatsApp.

Some of the reasons for using WhatsApp include "WhatsApp instant messaging makes learning easy, faster to share knowledge with their friend informal class although an informal, the student also easier to prepare before the class (to confirm the schedule, time and the material), attention and focus group discussion and improve student by s participation in collaborative by using Whatsapp [5]". The use of WhatsApp Messenger as a learning medium has proven to be quite useful for online teaching and learning [6]. The results of the study [7] also show positive things regarding the use of wa, namely integration of WhatsApp with group investigation method could cause the positive communication between student and lecturer. Discussion in this learning was well done, the student's knowledge could appear in a group and the information could spread evenly and quickly. In addition, WhatsApp in the educational process can also be used as a supporting technology [8].

But the use of WhatsApp also has obstacles, such as the finding [9] where almost half of students who study through WhatsApp feel burdened because there is no quota facility and the smartphone used is also not their own, some also use a neighbor's smartphone. But this is a technical problem, because after all, devices such as smartphones and internet connections are a necessity if you want to implement online learning.

Based on the problems above, this study aims to find an online assessment method that is effective and easy to do by almost all educators during this pandemic by 
utilizing familiar social media applications such as WhatsApp. In addition, this research is also motivated by the reality in the field which shows that not all teachers understand the benefits of the assessment or even use the results of the assessment to improve learning. So there is a need for a campaign to socialize this, one of which is through the publication of scientific papers resulting from this research that can be accessed by anyone who wants it.

\section{METHOD AND ASSESSMENT}

This study uses a research and development approach, with an orientation to develop and validate online assessment methods by utilizing google meet and whatsapp. The development model used was adapted from the 4-D model [10] with 4 stages, namely (1) define, including observation and journal analysis to determine the specifications of the assessment method that will be developed according to the needs of educators and students in online learning ; (2) designs; (3) develop, which includes product development and testing which is applied to a physics lecturer and Informatics Engineering student at a private university in Banten; and (4) disseminate, through scientific publication of the results of this research. In addition to observation, data was also collected using interview methods and document analysis, to validate the online assessment method as well as a reference to determine the level of effectiveness of the method.

Data collection techniques include: observation and literature study to determine the specifications of the assessment method that will be developed according to the needs of educators and students in online learning. In-depth interviews and document analysis, which were then analyzed qualitatively.

\section{RESULTS}

Based on interviews and observations that have been made, information was obtained that the process of assessing learning outcomes was only limited to assignments or take home exams as happened in several schools in Banten. There was even more extreme ones, namely in remote villages in Central Lampung district, especially for elementary and junior high school students, where they were only limited to doing exams at home by asking students to come to school to take exam questions according to the schedule that has been determined, then students collect answers the next day as well as take questions for the next subject. Where in the process, this activity is carried out with health protocols to avoid the spread of the corona virus. But this raises its own problems where the results of the assessment do not show the actual results or abilities of students because it is difficult to control that the completion of these questions is done by the students themselves. And even if the student does it himself, the result will not necessarily show the ability he has mastered because students can open books or access the internet. Moreover, the exam questions are in the form of multiple choice, making it easier for them to cheat. This can happen because these schools do not have online learning facilities such as LMS and the like. Even in the learning process, students are only given book loans for independent study and every few days they are sent practice questions through the WhatsApp application which then sends the answers to their assignments via WhatsApp. And even for elementary school children, communication via WhatsApp is carried out between teachers and students' guardians by asking students to study and then the guardian sends photos of proof of learning to the teacher. Of course this is very far from the desired criteria for online learning. It doesn't stop there, during the assessment, these students ask for help from others to do their exam questions, and for high school students they tend to work together and freely access the internet. Of course this assessment process is less effective because it cannot show the actual abilities or knowledge of these students.

Based on these problems, the researchers tried to develop an online assessment method that is easy to do by teachers and students who are unfamiliar with information technology, namely by using the Google Meet and WhatsApp application. Using Google Meet because it is easy to use and free as long as the teacher has an email. In line with that, [11] argues that Google Meet allows users to make video calls with 30 other users per meeting so that it can be an alternative media for the learning process. In addition, because the Google Meet application has advantages, namely it can help teachers explain the material in detail so that students understand more easily, and can also discuss directly with the teacher if there are things that need to be explained in more detail [12]. And the reason for using WhatsApp is because so far both teachers and students are used to using it, even they communicate related to school assignments also through this application. Such as the findings [13] where WhatsApp is useful for perfecting the means of sending assignments from lecturers to students because in terms of time it is very efficient, it doesn't take too long for lecture assignments to be sent easily and immediately accepted by the lecturer concerned.

The technical aspect of this assessment method is that the teacher prepares a meeting link on Google Meet by first accessing the Google Calendar to schedule the meeting. Then the meeting link was shared with the students via WhatsApp. After students access the meeting link, the teacher can do a 'share slide' to display exam questions, where these exam questions are 
displayed per number with a certain duration of time. After students work on the questions, they immediately send their answers to the teacher's WhatsApp number, this answer can be in the form of a handwritten photo if the exam questions are essays or direct text if the exam questions are in the form of multiple choice.

In this way, students will not have time to cheat because the duration of time provided is relatively short, and the time for sending the answers is well recorded on the teacher's smartphone. So that the results of this assessment can show the actual ability of students if the instruments used are of really high quality. And as for if the instrument has not been tested for quality, from the results of this assessment the teacher can also test the instrument in order to improve the quality of the instrument that can be used in the future.

This online assessment method has been tested on a physics lecturer and Informatics Engineering student at a private university in Banten. The results of the interview with one of the lecturers, it can be concluded that this method is very easy to apply, and controlling the students is easier, but there are a few obstacles when recording answers which take a relatively long time because they have to check one by one the answers sent via WhatsApp, and this of course will be very energyconsuming if the number of test takers is very large. Below is the full narrative.

"This method is very easy to use, even by ordinary people, but there are a few obstacles for those who are not familiar with Google Meet, so teachers should be given tutorials on making links and using Google Meet either directly or through video tutorials that can be accessed via Youtube, then this method can be applied. In addition, this method has a few obstacles when recording the results of student answers, if the number is small it is not too much of a problem, but if the number is very large it will take a lot of time and energy, if the question is in the form of multiple choice, maybe you can use google forms to save time in recording, but this also needs socialization so that teachers can make google forms like that. But whatever it is because one of the teacher's tasks is to do assessments, and even if the exam is conducted offline, it will also be the same as having to correct students' answers one by one no matter how many. And since I have not tested the questions that I use empirically, I can also use this data to measure the level of validity and reliability of the questions."

From the results of the interview, it is also necessary to have training or socialization on the use of Google Meet for teachers, this method can be carried out properly. The results of these students' answers can also be used as data to test the validity of the instrument, because validity and reliability for an instrument are very important to maintain and increase the value of validity and reliability so as to avoid disability [14]. And with the increase in the quality of this instrument, it is hoped that it can improve the assessment and quality of learning, such as the opinion [15] that improving the quality of learning can be done through improvements to the assessment used to measure student learning outcomes.

\section{CONCLUSIONS}

The findings of this study indicate that the assessment method that can be used by almost all educators at this time is by utilizing familiar social media applications such as WhatsApp. An online assessment method that is effective and easy to apply is by giving test questions directly through Google Meet or zoom meetings with a certain time duration for each question, and sending the answers via WhatsApp. This effectiveness and convenience is based on the results of interviews with research subjects who have used this method with the help of the Google Meet and WhatsApp applications where they find it easy to organize and evaluate learning outcomes. The results of the assessment also show the actual abilities of students because it is very difficult to be able to cheat or cooperate. In addition, the results of this assessment are also very useful for testing the quality of the questions themselves. So this method helps educators to measure the achievement of the competence of their students as well as to validate the test instruments that have been developed.

\section{REFERENCES}

[1] I. F. Ahmad, Alternative Assessment in Distance Learning in Emergencies Spread of Coronavirus Disease (Covid-19) in Indonesia. Jurnal Pedagogik, Vol. 7(1), 2020, pp. 195-222.

[2] Z. Am, Teknik Penilaian Hasil Pembelajaran. Jurnal Pemikiran dan Pencerahan, Vol. 14(2), 2018, pp. 53-62.

[3] K. Bashooir, \& Supahar, Validitas dan Reliabilitas Instrumen Asesmen Kinerja Literasi Sains Pelajaran Fisika Berbasis STEM. Jurnal Penelitian dan Evaluasi Pendidikan, Vol. 22(2), 2018, pp. 219-230.

[4] L. Cetinkaya, The Impact of Whatsapp Use on Success in Education Process. International Review of Research in Open and Distributed Learning, Vol. 18(7), 2017, pp.59-74.

[5] D. F. Dhahir, The Usability of Whatsapp Messenger as Online Teaching-Learning Media. Journal of Information Technology and Its Utilization, Vol. 3(2), 2020, pp. 48-52. 
[6] S. Hayati, and Lailatussaadah, Validitas dan Reliabilitas Instrumen Pengetahuan Pembelajaran Aktif, Kreatif dan Menyenangkan (PAKEM) Menggunakan Model Rasch. Jurnal Ilmiah DIDAKTIKA, Vol. 16(2), 2016, pp. 169-179.

[7] H. A. Nasution, and F. A. Nasution, Pengembangan Teknik dan Instrumen Asesmen Aspek Pengetahuan Berbasis Teknologi. TADBIR: Jurnal Manajemen Pendidikan Islam, Vol. 8(2), 2020, pp. 106-116.

[8] N. Nuriyah, Evaluasi Pembelajaran: Sebuah Kajian Teori. Jurnal Edueksos, Vol. 3(1), 2014, pp.73-86.

[9] P. S. Pernantah, Nova, and A. S. Ramadhani, Penggunaan Aplikasi Google Meet dalam Menunjang Keefektifan Belajar Daring Masa Pandemi Covid-19 di SMA Negeri 3 Pekanbaru. Pedagogi: Jurnal Ilmu Pendidikan, Vol. 21(1), 2021, pp. 45-50.

[10] H. Pratama, and S. Kartikawati, The Effect of WhatsApp Messenger as Mobile Learning Integrated with Group Investigation Method of Learning Achievement. International Journal of Science and Applied Science: Conference Series, Vol. 2(1), 2017, pp. 164-173.

[11] U. Rahaded, E. Puspitasari, and D. Hidayati, The Impact of Whatsapp Toward UAD Undergraduate Students' Behavior in Learning Process. Inter. Journal on Education, Management and Innovation (IJEMI), Vo. 1(1), 2020, pp. 55-68.

[12] Sartika. Kegunaan Whatsapp sebagai Media Informasi dan Media Pembelajaran pada Mahasiswa Ilmu Komunikasi STISIP Persada Bunda. Medium Jurnal Ilmiah Fakultas Ilmu Komunikasi Universitas Islam Riau, Vol. 6(2),2018, pp. 15-26.

[13] D. Sawitri, Penggunaan Google Meet untuk Work From Home di Era Pandemi Corona Virus Disease 2019 (Covid-19). Jurnal Prioritas: Jurnal Pengabdian Masyarakat, Vol. 2(1), 2020, pp. 1321.

[14] T. Sivasailam, D. S. Semmel, and M. I. Semmel, Instructional Development for Training Teacher of Exeptional Children. Indiana University, 1974.

[15] S. Suroto, and A. Nandiyanto, The Effectiveness of Using WhatsApp Social Media as Learning Media at Elementary School. Indonesian Journal of Multidiciplinary Research, Vol. 1(1), 2021, pp. 79-84. 